\title{
Rohingya Boat Refugees at Bay of Bengal and Obligations of the South East Asian States Under Soft Law
}

\author{
Hassan Al Imran ${ }^{1}$ D
}

Accepted: 24 September 2021 / Published online: 8 October 2021

(c) The Author(s), under exclusive licence to Springer Nature B.V. 2021

\begin{abstract}
The 1951 Refugee Convention and the 1967 Protocol are the only binding international instruments under which the parties of the instruments agree to protect refugees. However, there are gaps in the existing protection mechanisms for refugees at sea. Moreover, the South East Asian States are non-parties to the 1951 Refugee Convention; the States argue that they have no treaty obligation to accept Rohingya boat refugees. In this context, this article revisits the traditional view of 'soft laws', suggesting a fresh look at 'soft laws' regarding boat refugees. This article argues that even though the States are non-parties to international refugee law, the South East Asian States are members of the UN General Assembly, IMO, and ExCom. These international bodies have adopted numerous resolutions, guidelines and conclusions on refugee protection at sea; therefore, the States have international obligations to boat refugees according to Article 38(1)(C) of the Statute of the International Court of Justice 1945, the general principle of international law.
\end{abstract}

Keywords Refugee $\cdot$ Boat people $\cdot$ Non-refoulement $\cdot$ Extraterritorial $\cdot$ Sea $\cdot$ Rescue $\cdot$ Illegal

\section{Introduction}

The 1951 Convention Relating to the Status of Refugees ${ }^{1}$ and the 1967 Protocol Relating to the Status of Refugees ${ }^{2}$ are the only international instruments that specially provide the obligation of States for refugee protection. However, the South East Asian States' 1970's push back policy towards Vietnamese boat refugees, ${ }^{3}$ the

\footnotetext{
11951 Convention Relating to the Status of Refugees, 189 UNTS 137 (1951 Refugee Convention).

21967 Protocol Relating to the Status of Refugees, 606 UNTS 267 (1967 Protocol).

${ }^{3}$ Davies (2006a, b: 3).

Hassan Al Imran

hassanalimran99@gmail.com

1 University of Western Sydney, Sydney, NSW, Australia
} 
US's interdiction policy towards boat refugees, ${ }^{4}$ Australia's Tampa boat crisis ${ }^{5}$ and Italy's push back policy ${ }^{6}$ for refugee boats at high sea, all point to clear gaps in the existing protection mechanisms. Although the United Nations Convention on the Law of the Sea $1982^{7}$ provides obligations on coastal States and ship-masters for rescuing distressed persons at sea, in practice there remain significant challenges in refugee protection at sea, especially regarding disembarkation and search and rescue obligations. The Cap Anamur is an example of this issue. ${ }^{8}$ Moreover, during the COVID-19 pandemic, nation States worldwide are tightly controlling their borders, adopting a 'stop the refugee boat' policy; ${ }^{9}$ and even making deportation orders by violating the international law of non-refoulement. ${ }^{10}$ Since the onset of the pandemic, the push back policy has also been adopted by the South East Asian States (Bangladesh, Thailand, Malaysia and Indonesia) towards the Rohingya refugee boats. ${ }^{11}$ Therefore the Human Rights Group has urged these States to open their borders to boat refugees. ${ }^{12}$ The UN High Commissioner for Human Rights pointed out that it would be a 'human tragedy of terrible proportions' unless steps were taken to help the boat people. ${ }^{13}$ In reply, Bangladeshi Foreign Minister AK Abdul Momen argued that they were not obliged to accept the boat refugees; he claimed

\footnotetext{
${ }^{4}$ Legomsky (2006: 677).

5 Fox (2010: 356).

${ }^{6}$ Giuffré (2012: 692).

7 Specially, Article 98. United Nations Convention on the Law of the Sea 1982, 1833 UNTS 396.

8 Basaran (2014: 365).

9 Stierl. 13 May 2020. Migration: How Europe is using Coronavirus to reinforce its hostile environment in the Mediterranean. The Conversation. https://theconversation.com/migration-how-europe-is-usingcoronavirus-to-reinforce-its-hostile-environment-in-the-mediterranean-137840. Accessed.
}

on April 20 2021. Bickerton. 8 August 2020. Britain Could Copy Australia and Start 'Pushing Back' Migrant Boats After Record Numbers. Express. https://www.express.co.uk/news/uk/1320231/Immig ration-news-migrant-boats-border-force-refugees-Nigel-Farage. Accessed on April 20 2021. Bathke. 6 October 2020. Europe's Pushback of Migrants 'Shameful': UN Refugee Chief', Info Migrants. https:// www.infomigrants.net/en/post/27757/europe-s-pushback-of-migrants-shameful-un-refugee-chief. Accessed on April 202021.

10 Amnesty International. 6 August 2020. Trinidad and Tobago: Deportation of 165 Venezuelans Violates International Law. https://www.amnesty.org/en/latest/news/2020/08/trinidad-tobago-deportation165-venezuelans-violates-international-law/. Accessed on April 202021.

11 Human Rights Watch. 25 April 2020. Bangladesh: Rohingya Refugees Stranded at Sea: Allow Ashore Hundreds at Risk of Starvation, Provide Health Care. https:/www.hrw.org/news/2020/04/25/bangladeshrohingya-refugees-stranded-sea. Accessed on April 202021.

Human Rights Watch. 18 April 2020. Malaysia: Allow Rohingya Refugees Ashore: Covid-19 No Basis for Pushing Back Boats. https://www.hrw.org/news/2020/04/18/malaysia-allow-rohingya-refugeesashore.

Accessed on April 20 2021. Amnesty International. 20 October 2020. Indonesia: Hundreds of Rohingya Need Urgent Rescue Near Aceh Waters. https://www.amnesty.org.au/indonesia-hundreds-of-rohingyaneed-urgent-rescue-near-aceh-waters/. Accessed on April 202021.

12 Human Rights Watch. 12 June 2020. Malaysia/Thailand: Allow Rohingya Refugees Ashore, End Pushbacks, Grant Access to Aid and Asylum. https:/www.hrw.org/news/2020/06/12/malaysia/thailandallow-rohingya-refugees-ashore. Accessed on April 202021.

13 UN Rights Chief Urges Bangladesh to Accept Rohingya Boats. 27 April, 2020. Aljazeera https:// www.aljazeera.com/news/2020/04/rights-chief-urges-bangladesh-accept-rohingya-boats-2004271424 38774.html. Accessed on April 202021. 
that 'Bangladesh has already taken more than a million [of] Rohingya. We are running out of our generosity'. The Foreign Minister added that there were other coastal countries surrounding the Bay of Bengal, who should also be made responsible for accepting these boat refugees. ${ }^{14}$ The Bangladeshi Foreign Minister pointed out that because of the COVID-19 pandemic, Bangladesh now had to deal with thousands of deportees who had returned home; therefore, he said, 'we have no room to shelter any foreign people or refugees'. ${ }^{15}$

Human Rights Watch stresses that the Covid-19 pandemic cannot be used as grounds for refusal of refugees to the Bay of Bengal, stating that:

Under international law, public health measures taken in response to the Covid-19 pandemic must be proportionate, non-discriminatory, and based on available scientific evidence. It may be reasonable to subject those who arrive to a period of isolation or quarantine. But the pandemic cannot justify a blanket ban such as Bangladesh's refusal to allow any Rohingya now or in the future to disembark. ${ }^{16}$

On the other hand, there is no refugee law or human rights law in Asia similar to those of Europe, Africa or Latin America. Asian States are non-parties to international refugee law due to the 'Eurocentric' reasoning of the 1951 Refugee Convention. ${ }^{17}$ Moreover, as of 2021, none of the South East Asian coastal States (Bangladesh, Thailand, Malaysia, Myanmar and Indonesia) were parties either to the 1951 Refugee Convention or the 1967 Protocol. ${ }^{18}$ In fact, there is no current domestic law for refugee protection in the region. ${ }^{19}$ Accordingly, there is a legal vacuum regarding refugee protection in South East Asia. In this context, the UNHCR states that:

Available protection space for refugees, asylum seekers and stateless people in the region is fragile and unpredictable, due to a lack of national legal frameworks in most South-East Asian countries...There is also an increase in maritime "push backs" and instances of refoulement... The lack of asylum laws and diversity of national legal frameworks, as well as government practices and protection environments in the region's countries, make achieving regional harmonization challenging. ${ }^{20}$

\footnotetext{
${ }^{14}$ Mahmud. 25 April, 2020. Rohingya Stranded at Sea, Bangladesh Says Not Its Responsibility. Aljazeera. https://www.aljazeera.com/news/2020/04/rohingya-stranded-sea-bangladesh-responsibility-20042 5082607464.html. Accessed on April 20, 2021.

15 Bangladesh: 'Not a Single Rohingya Will be Allowed to Enter'. 23 April 2020. Radio Free Asia. https://www.rfa.org/english/news/myanmar/bangladesh-rohingya-04232020195727.html. Accessed on April 202021.

${ }^{16}$ Human Rights Watch, Bangladesh: Rohingya Refugees Stranded at Sea, supra note 11.

${ }^{17}$ Davies (2006a, b: 562).

${ }^{18}$ UNHCR, Global Appeal 2021 Update, at 160-161,<https://reporting.unhcr.org/sites/default/files/ ga2021/pdf/Global_Appeal_2021_full_lowres.pdf > Accessed on April 202021.

${ }^{19}$ Adelman (ed). 2008. Protracted Displacement in Asia: No Place to Call Home. Ashgate Publishing.

${ }^{20}$ UNHCR, South East Asia: Global Appeal (Update 2015) at 2,<https://www.unhcr.org/publicatio ns/fundraising/5461e60a558/unhcr-global-appeal-2015-update-south-east-asia-subregional-overview. html > Accessed on April 202021.
} 
There are also several unclear areas in international law regarding refugee protection at sea. ${ }^{21}$ Every year hundreds of boat refugees die due to the push back policy of coastal States, and yet none of these States are held responsible for the deaths. ${ }^{22}$ Thus, protection of boat refugees is a challenging issue. Boat refugees are rejected at the frontiers before they have a chance to submit their applications; they are intercepted, turned back to sea, or prevented from landing. These areas are denoted as grey zones in international law. ${ }^{23}$ While the coastal States adopt a push back policy for boat refugees, they challenge the non-refoulement principle. $^{24}$ The obligation of coastal States to boat refugees remains an undecided issue in international law $^{25}$; accordingly the question arises, do the boat refugees have any right to be rescued at sea? $^{26}$

Against this backdrop, this paper argues that the protection regime for boat refugees should not be allowed to fall through the gaps in modern international law. In particular, the UN General Assembly resolutions, the UNHCR and IMO guidelines and the Executive Committee of UNHCR's (ExCom) recommendations have been adopted especially for boat refugees and the non-refoulement obligations. Accordingly, as a member of the United Nations (UN), IOM and ExCom, a State cannot ignore the guidelines and resolutions of international law, which are considered 'soft law'. ${ }^{27}$ Soft laws are non-binding agreements, which are viewed as 'political commitments' and 'gentlemen's agreements'. Under 'soft laws, States agree on informal normative clauses that place political and moral obligations on the States to follow their international commitments. This is no different to treaty obligations, as in both situations (treaties and soft laws) States willingly undertake their international obligations. ${ }^{28}$ As a result, as general principles of international law, States have obligations to follow these soft laws. In this context, this article will first ask who the Rohingya refugees are, and why are they at sea? Secondly it will focus on the gaps in existing international law in refugee protection at sea, looking for solutions. Thirdly this article will define the soft law and focus on the UN General Assembly, the UNHCR, ExCom and IMO's resolutions, recommendations and policies on boat refugees. Fourthly, it will evaluate the contribution of the soft laws regarding refugee protection at sea. Finally, in the conclusion, it will suggest that States have international obligations to protect boat refugees under normative rules of the soft law in modern international law, which has the same value as a binding agreement or treaty.

\footnotetext{
21 Mann (2018: 347).

22 Ibid. 369-370.

23 Stoyanova (2008:11).

24 Trevisanut (2008: 205).

25 Proelss (2008:1).

26 Papastavridis (2014: 17-32).

27 Article 38(1) (C), Statute of the International Court of Justice, 18th April 1946, 33 UNTS 993.

28 Dörr and Schmalenbach (eds.) (2018: 43-44).
} 


\section{Who are the Rohingya Boat Refugees?}

The Rohingya are a Muslim ethnic minority from the Rakhine state of Myanmar. In 1982, Myanmar (previously known as Burma) adopted its new citizenship law-The Burma Citizenship Law $1982,{ }^{29}$ where a total of 135 national races were named, but the Rohingya group was excluded from this list. ${ }^{30}$ Thus, Myanmar's government refused to recognise the Rohingya as one of the country's ethnic groups. The Rohingya became 'stateless entities'; they are unwanted and unrecognised by the State as having legal status. ${ }^{31}$

In fact, the identity of Rohingyan people as a minority group in Myanmar has been reconstructed over the years due to Burma's political agenda. The development of Burmese nationalism, politicisation of identity for the Burmese majority, removal of citizenship, and ethnic divisions and violence in Myanmar society all played substantial roles in recreating their identity as a minority group. ${ }^{32}$ In the past the Rohingya have experienced British colonial rule (1824-1948), Japanese occupation during the Second World War and military dictatorship. Lawmakers under these regimes created many laws and policies that directly and indirectly added to the Rohingyan burden of persistent persecution in Myanmar today. ${ }^{33}$ In particular, citizenship status is a legal connection between a citizen and a State which creates civil and political rights and links the identity of an individual to a State. A stateless person therefore cannot claim these rights to the State. ${ }^{34}$ In reality, although the 1982 Citizenship Act made the Rohingyas stateless local troubles, especially Myanmar's extremist Buddhist policies made them the most vulnerable minority in the world. As long as there is no refugee protection law in South East Asia, refugees have no legal right to claim refugee status in the neighbouring States, making the situation more critical for the Rohingyas.

Over the last few decades, various reports have suggested the possibility of genocide being committed against this group. They have certainly been facing discriminatory policies in deprivation of their basic rights, including restriction of access to food, medicine and jobs. In practice, torture is part of their daily life. Because of this, many Rohingya are fleeing Myanmar to the neighbouring coastal States of

\footnotetext{
29 Burma Citizenship Law, 15 October 1982 (1982 Citizenship Law).

${ }^{30}$ Human Rights Watch. 13 January 2015. Burma: Amend Biased Citizenship Law 1982 Act: Fuels Repression, Deprives Rohingya Muslims of Basic Rights. https://www.hrw.org/news/2015/01/13/burmaamend-biased-citizenship-law. Accessed on April 202021.

31 Haque (2017: 454).

32 Alam (2018: 180-210).

33 Alam (2019: 4).

34 Parashar and Alam (2018: 94-108).
} 
South East Asia. ${ }^{35}$ Amnesty International declared the Rohingyas the most persecuted refugees in the world. ${ }^{36}$

In 2017, an 'Independent International Fact-Finding Mission on Myanmar' (IIFFMM) was established by the United Nations Human Rights Council for the alleged human rights violations by military and security forces of Myanmar against the Rohingya people. The Fact-Finding Mission found sufficient evidence of violation of human rights, including grave crimes and genocide, in Myanmar's Rakhine State. ${ }^{37}$ Following the Fact-Finding report, Gambia filed a genocide case against Myanmar in the International Court of Justice (ICJ) in 2019 under the 1948 Convention on the Prevention and Punishment of the Crime of Genocide. ${ }^{38}$ Gambia and Myanmar have both ratified the 1948 Genocide Convention; they have obligations to prevent genocide under the Convention. After the preliminary hearing, the highest international court in the world considered that the court has prima facie jurisdiction of the case, ${ }^{39}$ and as a provisional measure, the ICJ unanimously ruled that Myanmar should protect the Rohingya people from genocide. ${ }^{40}$ However, in reality, the ICJ will take several years to finalize its adjudication of the case, so it is too early to comment on this issue. Nonetheless, it is a positive sign that the world community is concerned about the rights of Rohingya people. However, Myanmar has not yet taken any visible actions that would indicate any goodwill or intention to stop the genocide, persecution and discriminatory policy against the Rohingya group. ${ }^{41}$ Rohingyas are still considered 'stateless'. In the recent general election in Myanmar, held on 8 November 2020, more than one million Rohingyas were denied voting rights. ${ }^{42}$ Therefore, whenever the opportunity arises, many Rohingyas try to escape from Myanmar to other countries. With the recent military coup in Myanmar (2 February 2021) the Rohingya people are expected to face further persecution and exclusion from their human rights. Due to its geographic location, the Rakhine state

\footnotetext{
35 Southwick (2015: 138); Allard K. Lowenstein International Human Rights Clinic (Yale Law School). 2015. Persecution of the Rohingya Muslims: Is Genocide Occurring in Myanmar's Rakhine State? A Legal Analysis (Research Report). https://law.yale.edu/sites/default/files/documents/pdf/Clinics/fortifyrig hts.pdf. Accessed on 20 April 2021.

36 Amnesty International. 26 September 2017. Who Are the Rohingya and What is Happening in Myanmar? https://www.amnesty.org.au/who-are-the-rohingya-refugees. Accessed on 20 April 2021.

37 United Nations Human Rights Council. Independent International Fact-Finding Mission on Myanmar. https://www.ohchr.org/en/hrbodies/hrc/myanmarffm/pages/index.aspx. Accessed on 20 April 2021.

38 ICJ. 11 November 2019. The Republic of the Gambia institutes proceedings against the Republic of the Union of Myanmar and asks the Court to indicate provisional measures' (Press Release, No. 2019/47). https://www.icj-cij.org/en/case/178. Accessed on 20 April 2021.

39 ICJ. 23 January 2020. Application of the Convention on the Prevention and Punishment of the Crime of Genocide (The Gambia v Myanmar). Order. https://www.icj-cij.org/en/case/178. Para. 37. Accessed on 20 April 2021.

40 Ibid. para. 76-86.

41 Myanmar's Genocide Against Rohingya Not Over, Says Rights Group. 24 Nov. 2020. The Guardian. https://www.theguardian.com/world/2020/nov/23/myanmar-is-still-committing-genocide-against-rohin gya-says-rights-group. Accessed on 20 April 2021.

42 Rebecca Ratcliffe. 6 November 2020. Myanmar Minorities, Including Rohingya, Excluded from Voting in Election. The Guardian. https://www.theguardian.com/world/2020/nov/06/myanmar-minoritiesrohingya-excluded-voting-election-poll-aung-san-suu-kyi-rights. Accessed on 20 April 2021.
} 
in Myanmar shares a common border with the Bay of Bengal sea, thus a large number of Rohingyas try to flee to neighbouring states by sea. However, they are pushed back by the States, to the perils of the Bay of Bengal and the Andaman sea, doubling their risks - on land and at sea.

Even though international law has progressed in the protection of refugees, there remain some unclear areas for boat refugees. The next section of this article focuses on international law and the challenges of refugee protection at sea.

\section{Refugees at Sea: Challenges in International Law and a Solution}

The 1951 Refugee Convention and the 1967 Protocol form the foundations of international refugee law. At present 148 States are parties to one or both of these instruments. ${ }^{43}$ The 1951 Convention defines who is a refugee. If the person fulfils the requirements, then he/she is eligible to receive refugee status from another State. According to Article I(A)(2) of the 1951 Refugee Convention, a person is a refugee who:

owing to well-founded fear of being persecuted for reasons of race, religion, nationality, membership of a particular social group or political opinion, is outside the country of his nationality and is unable or, owing to such fear, is unwilling to avail himself of the protection of that country; or who, not having a nationality and being outside the country of his former habitual residence as a result of such events, is unable or, owing to such fear, is unwilling to return to it.

The Refugee Convention particularly ensures that the contracting parties should not impose any penalty on any refugees who come directly from a territory where their life or freedom was threatened due to persecution. ${ }^{44}$ And most importantly, the Convention ensures non-refoulement. Article 33(1) states that:

No Contracting State shall expel or return ("refouler") a refugee in any manner whatsoever to the frontiers of territories where his life or freedom would be threatened on account of his race, religion, nationality, membership of a particular social group or political opinion.

Article 33(1) of the 1951 Refugee Convention is known as the principle of nonrefoulement which is considered the cornerstone of international refugee protection. ${ }^{45}$ However, if a refugee is deemed a threat to the national security, then a

\footnotetext{
43 UNHCR. States Parties to the 1951 Convention relating to the Status of Refugees and the 1967 Protocol. https://www.unhcr.org/protect/PROTECTION/3b73b0d63.pdf. Accessed on 20 April 2021.

44 Article 31(1), the Refugee Convention 1951.

45 UNHCR (2007). Advisory Opinion on the Extraterritorial Application of Non- Refoulement Obligations under the 1951 Convention relating to the Status of Refugees and its 1967 Protocol. Para. 2(25). http://www.refworld.org/docid/45f17a1a4.html. Accessed on 20 April 2021.
} 
State may deny the entry of a refugee. ${ }^{46}$ However, the Refugee Convention does not provide any particular procedures for the determination of refugee status. A State enjoys its own discretion to allow any refugee into its land according to its domestic law. ${ }^{47}$ Moreover, according to the 1951 Convention, to claim refugee status, an asylum seeker has to physically present in the land of the State. Even if refugees arrives by international air or sea, or on-board a ship, unless and until they are physically present in a territory, they cannot claim international protection under international refugee law. ${ }^{48}$ In fact, extraterritorial application of non-refoulement is 'less clear.' ${ }^{49}$ Atle Grahl-Madsen and Paul Weis closely observed the drafting procedure of the 1951 Refugee Convention, they noted in their commentaries that according to The Travaux Préparatoires and drafting history, extraterritorial application of the nonrefoulement principle is not supported at sea. Atle Grahl-Madsen notes that:

If a Contracting State has placed its frontier guards right at the frontier, and has fenced off its territory, so that no one can set foot on it without having been permitted to do so, the State may refuse admission to any comer without breaking its obligations under Article 33. ${ }^{50}$

Paul Weis further notes that, 'The State admitting the refugee is not obliged to grant him asylum, and may even expel him to another country,' and 'refoulement' also covers rejection at the frontier'. ${ }^{51}$ Again according to the text of the Article 33(1), "No Contracting State shall expel or return ("refouler") a refugee in any manner whatsoever to the frontiers of territories where his life or freedom would be threatened'. Therefore, denial of entry of refugee boats at territorial waters or rejection of entry of refugee boats at territorial seas or push back of the refugee boats to sea cannot be paralleled with breach of the principle of non-refoulement. ${ }^{52}$

Consequently, it remains unclear whether or not the 1951 Refugee Convention is applicable beyond land territory of a State at territorial sea. However, the UNHCR suggests that if the 1951 Refugee Convention is considered with its object and purpose, including the broader meaning of treaty interpretation of the Vienna Convention, ${ }^{53}$ then the refugee law has extraterritorial effect and a State is obliged to protect

\footnotetext{
46 Articles 31(2) and 33(2), the 1951 Refugee Convention.

47 UNHCR (2011a, b). Handbook and Guidelines on Procedures and Criteria for Determining Refugee Status under the 1951 Convention and the 1967 Protocol Relating to the Status of Refugees. HCR/1P/4/ ENG/REV. https://www.refworld.org/pdfid/4f33c8d92.pdf. Accessed on 20 April 2021. The UNHCR Handbook states that: 'In particular, the Convention does not indicate what type of procedures are to be adopted for the determination of refugee status. It is therefore left to each Contracting State to establish the procedure that it considers most appropriate, having regard to its particular constitutional and administrative structure', see para. 189.

48 Hathaway and Foster (2014: 27-28).

49 Kalin, Martina Caroni \& Lukas Heim (2011: 1361).

50 Grahl-Madsen (1997). Commentary of the Refugee Convention 1951 (Articles 2-11, 13-37), at 137. https://www.refworld.org/docid/4785ee9d2.html. Accessed on 20 April 2021.

51 Weis (1990). The Refugee Convention, 1951: The Travaux Préparatoires Analysed with a Commentary, at 245. https://www.refworld.org/docid/53e1dd114.html. Accessed on 20 April 2021.

52 Goodwin-Gill and McAdam (2007: 277-278).

53 Article 31(1) of the 1969 Vienna Convention on the Law of Treaties, 1155 U.N.T.S. 331, (entered into force 27 January 1980) (1969 Vienna Convention).
} 
boat refugees. ${ }^{54}$ But, in practice, it has been observed that none of the States follow the UNHCR's interpretation.

In reality, most of the Asian States have not yet acceded to international refugee law. There is no refugee law or human rights law in Asia like that of Europe or Africa. Thus, in this legal vacuum, refugee protection remains a challenging issue in Asia. Between 2014-2015, during the Bay of Bengal and Andaman Sea Rohingya boat refugee crisis, the coastal States of South East Asia (Thailand, Indonesia, Malaysia and Bangladesh) pushed back the refugee boats; at that time around 1500 refugees and asylum seekers died at sea. ${ }^{55}$ Clearly, the States of this region are ignoring their international responsibility to boat refugees. ${ }^{56}$

In practice, the extraterritorial application of non-refoulement has been examined by the courts. The United States Supreme Court in Sale v. Haitian Centers Council held that the 1951 Refugee Convention had no application at high sea. ${ }^{57}$ The same conclusion was reached by the UK House of Lords in the Roma case. ${ }^{58}$ The highest Court of the UK ruled that 'the negotiating history of Article 33 [1951 Refugee Convention] affirmatively indicated that it was not intended to have extraterritorial effect'. ${ }^{59}$ Similarly, the High Court of Australia in CPCF v Minister for Immigration and Border Protection ${ }^{60}$ clearly declared that 'a state's obligations under the [1951 Refugee] Convention arise only with respect to persons who are within that state's territory'. ${ }^{61}$ Therefore, the highest courts of the US, the UK and Australia ruled that the non-refoulement principle has territorial limitation, not applicable beyond its land territory. Accordingly, there are gaps in the refugee protection regime for boat refugees who try to arrive by a sea route or through an international water zone.

In the context of boat refugees, the law of the sea also needs to be considered. The UN Convention of the Law of the Sea $1982^{62}$ is considered as a constitution of the sea, where a coastal State's sovereignty rights has been ensured. In particular, Article 3(1) of UNCLOS III states: 'The sovereignty of a coastal State extends beyond its land territory and internal waters'. Article 3(2) also provides that limit of sovereignty at territorial sea is 12 maximum nautical miles. According to Articles $19(2)(\mathrm{g})$ and 21(1)(h) a coastal State may adopt laws and regulations for 'the prevention of infringement of the customs, fiscal, immigration or sanitary laws and regulations of the coastal States in their territorial seas. Therefore, coastal States have legal authority to control their ports and territory; in practice ports of a State are not open

\footnotetext{
54 UNHCR, supra note 45, paras. 23-32.

55 UNHCR, South-East Asia, Mixed Maritime Movements (April-June 2015: Highlights) at page 2,

$<$ https://reliefweb.int/sites/reliefweb.int/files/resources/554c6a746_0.pdf >. Accessed on April 16, 2021.

56 Ghráinne (2015: 109).

57 Sale v. Haitian Centers Council, 509 US 155 (1993) 183.

58 Regina v Immigration Officer at Prague Airport and Another, Ex parte European Roma Rights Centre and Others [2004] UKHL 55. (Roma case).

59 Ibid., para 68.

60 CPCF v Minister for Immigration and Border Protection [2015] HCA 1.

61 Ibid., para 461.

62 Convention on the Law of the Sea, Dec. 10, 1982, 1833 U.N.T.S. 397 (UNCLOS 1982).
} 
to non-citizens unless permitted entry. On the other hand, according to Article $98(1)$ of the UN Convention of the Law of the Sea:

Every State shall require the master of a ship flying its flag, in so far as he can do so without serious danger to the ship, the crew or the passengers: (a) to render assistance to any person found at sea in danger of being lost; (b) to proceed with all possible speed to the rescue of persons in distress, if informed of their need of assistance, in so far as such action may reasonably be expected of him; (c) after a collision, to render assistance to the other ship, its crew and its passengers and, where possible, to inform the other ship of the name of his own ship, its port of registry and the nearest port at which it will call.

According to the text of Article 98(1), the master of the ship shall be required to proceed to the rescue of persons in distress so far as he can do so without serious danger to the ship, the crew or the passengers. Thus, the obligation to 'render assistance to any person found at sea' depends greatly on the discretion of a ship-master. ${ }^{63}$ In addition, there is no mandatory obligation of coastal States under international law regarding the disembarkation of rescued persons. ${ }^{64}$ In practice, disembarkation of rescued persons depends on the willingness of a coastal State. This situation is a 'maritime legal black hole. ${ }^{95}$ International refugee law provides certain rights for refugees which are available when the refugee is within the border of a State. The refugee law does not, however, provide any obligation to the States to rescue refugees from drowning or attempt to save those whose life is in danger at sea. ${ }^{66}$

In general, due to the principle of sovereignty, international law cannot extend a State's human rights obligations beyond its national jurisdiction. ${ }^{67}$ Extraterritorial obligation of human rights treaties is an unsettled issue in international law. ${ }^{68}$ In this regard the most notable decision is the ICJ's ruling on the Construction of a Wall in the Occupied Palestinian Territory case where the ICJ considered the extraterritorial application of human rights treaties. ${ }^{69}$ The ICJ critically examines the text of Article 2(1) of International Covenant on Civil and Political Rights (ICCPR) ${ }^{70}$ in the decision. Article 2(1) of ICCPR provides that:

Each State Party to the present Covenant undertakes to respect and to ensure to all individuals within its territory and subject to its jurisdiction the rights recognized in the present Covenant, without distinction of any kind, such as race,

\footnotetext{
63 Pugash (1977: 577), Lansakara (2014-2015: 288).

64 Coppens and Somers (2010: 377).

65 Mann (2018: 347).

66 Mann (2020: 607).

67 Skogly (2006: 25).

68 Ibid 30.

69 ICJ, Legal Consequences of the Construction of a Wall in the Occupied Palestinian Territory, Advisory Opinion, I. C. J. Reports 2004, p. 136.

70 International Covenant on Civil and Political Rights, 16 December 1966, UNTS, Vol. 999, 171.
} 
colour, sex, language, religion, political or other opinion, national or social origin, property, birth or other status.

In the advisory opinion of the Construction of a Wall in the Occupied Palestinian Territory case, the ICJ opined that 'jurisdiction of States is primarily territorial'. ${ }^{71}$ The ICJ further stated that if the object and purpose of Article 2(1) of International Covenant on Civil and Political Rights is considered then 'it may sometimes be exercised outside the national territory ${ }^{\text {, }}$; thus, 'the Covenant [ICCPR] is applicable where the State exercises its jurisdiction on foreign territory'. ${ }^{73}$ In the decision, ICJ took into consideration the Lopez Burgos v Uruguay case, where the State's human rights violation was examined, in relation to conduct of its armed forces during armed conflict beyond its land territory. ${ }^{74}$ However, it could be contended that the Lopez Burgos v Uruguay case is not related to extraterritorial obligation to refugees, or to rescue obligation to refugees at sea. Therefore, it could be suggested that, if the object and purpose of the ICCPR is considered, then it has beyond territorial effect; otherwise, it is unclear whether the Covenant is applicable at sea, that isbeyond the land territory.

However, in the same decision of Construction of a Wall in the Occupied Palestinian Territory the ICJ also suggested a different conclusion to the International Covenant on Economic, Social and Cultural Rights. ${ }^{75}$ In its advisory opinion the ICJ states that:

The International Covenant on Economic, Social and Cultural Rights contains no provision on its scope of application. This may be explicable by the fact that this Covenant guarantees rights which are essentially territorial. ${ }^{76}$

In this vein, Thomas Gammeltoft-Hansen notes, regarding State's extraterritorial obligation of human rights treaties, that 'neither international human rights law, nor the law of treaties contain any general rules on extraterritorial application'. ${ }^{77}$

As a result, this research submits that extraterritorial application of the nonrefoulement obligation of a State under the 1951 Refugee Convention is an unclear issue. The text of Article 98 of UNCLOS III does not clearly indicate any mandatory obligation to ship masters to rescue any distressed persons at sea. Extraterritorial application of human rights obligations at sea to boat refugees is also an undecided issue in international law. Thus, the existing international refugee law, law of

\footnotetext{
71 Ibid., at 179, paras 109 .

72 Ibid.

73 Ibid.

74 Lopez Burgos v Uruguay, Saldias de Lopez (on behalf of Lopez Burgos) v Uruguay, Merits, Communication No 52/1979, UN Doc CCPR/C/13/D/52/1979, IHRL 2796 (UNHRC 1981), 29th July 1981.

75 International Covenant on Economic, Social and Cultural Rights, 16 December 1966, UNTS Vol. $993,3$.

76 ICJ, Legal Consequences of the Construction of a Wall, supra note 69, at 180, para. 112.

77 Gammeltoft-Hansen (2014: 118).
} 
the sea and human right treaties do not provide any clear obligations to States on refugee protection at sea.

On the other hand, the UNCLOS III states that ' sovereignty over the territorial sea is exercised subject to this Convention and to other rules of international law' ${ }^{78}$ Moreover, Article 38(1)(C) of the Statute of the International Court of Justice 1945 states that sources of international law include 'the general principles of law recognized by civilized nations'. ${ }^{79}$ In this context, this paper suggests that 'other rules of international law' and 'the general principles of law recognized by civilized nations' indicate 'soft law'. The General Assembly of United Nations, United Nation High Commissioner for Refugees (UNHCR), Executive Committee of UNHCR (ExCom) and International Maritime Organization (IMO) have adopted numerous resolutions, guidelines, conclusions and polices as soft law in relation to refugee protection at sea and non-refoulement obligations of States to boat refugees. South East Asian States are members of the UN General Assembly, ${ }^{80}$ ExCom $^{81}$ and IMO. ${ }^{82}$ Accordingly, as members of the international organisations and bodies, the States have general obligations to ensure international commitments and human rights. ${ }^{83}$ The High Court of Australia in Minister for Immigration and Ethnic Affairs $v$ Teoh held that if a State gives its consent to an international treaty, then there is a general expectation that the State should fulfil its international commitments and promises accordingly. ${ }^{84}$ Therefore, this article argues that a State has obligations to assist boat refugees under the general provisions of international law, i.e. soft law.

The following sections of this article focus on the details of soft laws in specific relation to boat refugees. First, it defines soft law and its importance in international

\footnotetext{
78 Article 2(3), UNCLOS 1982.

79 Article 38 of the Statute of the International Court of Justice states: The Court, whose function is to decide in accordance with international law such disputes as are submitted to it, shall apply: (a) international conventions, whether general or particular, establishing rules expressly recognized by the contesting states; (b) international custom, as evidence of a general practice accepted as law; (c) the general principles of law recognized by civilized nations.

${ }^{80}$ Bangladesh (date of admission in United Nations on 17 September 1974), Indonesia (date of admission in United Nations on 29 September 1950), Malaysia (date of admission in United Nations on 17 September 1957), Myanmar (date of admission in United Nations on 19 April 1948) and Thailand (date of admission in United Nations on 16 December 1946). United Nations, General Assembly and Member States $<$ https://www.un.org/en/member-states/ $>$.

81 Bangladesh and Thailand are members of Executive Committee of UNHCR (ExCom). Indonesia, Malaysia and Myanmar participated in the ExCom meetings as observers. See, UNHCR, Report of the Seventieth Session of the Executive Committee of the High Commissioner's Programme < https://www. unhcr.org/en-au/excom/excomrep/5db958137/70h-session-executive-committee-report-seventieth-sessi on-executive-committee.html > Accessed on April 202021.

82 Bangladesh (joined in IMO in 1976), Indonesia (joined in IMO in 1961), Malaysia (joined in IMO in 1971), Myanmar (joined in IMO in 1951) and Thailand (joined in IMO in 1973). IMO, Member States < https://www.imo.org/en/OurWork/ERO/Pages/MemberStates.aspx > Accessed on April 202021.

83 Article 1(3) of the UN Charter provides that the purposes and the principles of UN as: To achieve international co-operation in solving international problems of an economic, social, cultural, or humanitarian character, and in promoting and encouraging respect for human rights and for fundamental freedoms for all without distinction as to race, sex, language, or religion.

84 Minister for Immigration and Ethnic Affairs v Teoh (1995) 128 Australian Law Reports 353. See also, Hassan and Al Imran (2020: 187-241).
} 
law. Next, it examines the soft laws provided by UN General Assembly, UNHCR, ExCom of UNHCR and IMO in relation to boat refugees.

\section{Soft Law}

International law is defined as "consisting of rules and principles of general application dealing with the conduct of States and of international organizations and with their relations inter se, as well as with some of their relations with persons, whether natural or juridical'. ${ }^{85}$ Article $38(1)(\mathrm{C})$ of the Statute of the International Court of Justice 1945 states that 'the general principles of law recognized by civilized nations' are also sources of international law. Accordingly, soft laws provide valuable tools under international law for the protection of refugees. ${ }^{86}$

Although soft law is not a legal source of international law like international treaties and conventions, nevertheless, it makes a valuable contribution in three ways: it provides evidence of customary law; it gives guidance on the application of treaties; and it creates a platform of inter-State cooperation. ${ }^{87}$

Soft law has been defined as 'normative provisions contained in non-binding texts' ${ }^{88}$ It is also defined as non-binding rules or instruments that interpret our understanding of binding legal rules or represents promises that in turn create an expectation about future conduct. ${ }^{89}$ Soft law rules are considered 'quasi-legal'. 90 Even though, unlike a treaty, soft law is not legally binding, it has legally non-binding commitments which follow its legal obligations. ${ }^{91}$ Soft law can fill the gaps in treaty laws for specific issues during its application. ${ }^{92}$

Article 26 of the 1969 Vienna Convention states that international agreement must be interpreted in good faith. While the soft law is the State's 'gentlemen's agreement', its legal enforcement and the responsibility of the State still depends on treaty interpretation. ${ }^{93}$ Soft law or a non-binding instrument can be a useful tool to establish widespread and consistent State practice or evidence of opinio juris. ${ }^{94}$

In fact, soft law covers 'soft treaty provisions, non-binding or voluntary resolutions and recommendations, codes of conduct and standards formulated by international organisations and conference of the parties'. ${ }^{95}$ In this context, the UN General Assembly resolutions, the guidelines and conclusions of UNHCR and its

\footnotetext{
85 Malanczuk (1997: 1).

${ }^{86}$ Chetail (2012: 56-92).

87 Ibid 85.

88 Elias and Chin Lim (1997: 3).

89 . Guzman and Meyer (2010: 174).

90 Ibid. 172.

91 Ibid. 222.

92 Chetail, supra note 86, 86.

93 Kolb (2016: 19).

94 Boyle (1999: 903).

95 Castillo (2014: 69).
} 
Executive Committee (ExCom) of the UNHCR ${ }^{96}$ and IMO guidelines on refoulement, the search, rescue and protection of asylum seekers at sea, each provide a significant contribution as soft law. ${ }^{97}$ The following sections examine the guidelines and resolutions.

\section{(A) General Assembly, Non-Refoulement and Refugees at Sea}

The General Assembly is the parliamentary body of the United Nations and comprises the representatives of all the member States. ${ }^{98}$

On numerous occasions the General Assembly has called on the State parties to follow the international instruments to protect refugees under humanitarian considerations and has also urged States to secure human rights, particularly the nonrefoulement and rescue of refugees at sea. ${ }^{99}$

The General Assembly reaffirmed that the 1951 Convention and the 1967 Proto$\mathrm{col}$ are the foundation of the international refugee regime, and recognised the importance of their full application by State parties. It has urged to all States, non-governmental and other organisations to cooperate to provide refugee protection according to the spirit of international solidarity and burden-sharing responsibility. ${ }^{100}$ The General Assembly also expressed its concern regarding the continued violation of the principle of non-refoulement, stressed the need to strengthen the measures to protect refugees against violation and also appealed to all the States who have not yet signed the 1951 Refugee Convention and the 1967 Protocol to consider acceding to the instruments to enhance their universal character. ${ }^{101}$

On another occasion, in 1981 the UN General Assembly considered the 'Report of the United Nations High Commissioner for Refugees' and drew the world's attention to the problem of refugees rescued at sea and the difficulties encountered around their disembarkation, including threats of refoulement. ${ }^{102}$ It also expressed its concern at the large numbers of asylum seekers who have lost their lives at sea trying to reach safety, and encouraged international cooperation to further strengthen search

\footnotetext{
${ }^{96}$ UNHCR (2014a, b). A Thematic Compilation of Executive Committee Conclusions. Division of International Protection, Geneva. (7th edition). https://www.refworld.org/docid/5698c1224.html. Accessed on 20 April 2021.

See also, UNHCR (2017). General Legal Considerations: Search-and-Rescue Operations Involving Refugees and Migrants at Sea. https://www.refworld.org/docid/5a2e9efd4.html. Accessed on 20 April 2021.

${ }^{97}$ See, Harrison (2011:176-178, 278).

${ }^{98}$ Chapter IV, UN Charter, especially Article 9, 10 and 11; United Nations, Charter of the United Nations, 24 October 1945, 1 UNTS XVI. Now the UN has 193 member states:<http://www.un.org/en/ member-states/> Accessed on April 202021.

${ }^{99}$ UNHCR. Thematic Compilation of General Assembly and Economic and Social Council Resolutions (2015: 226-246, 289-297, 406-412, 447-448. https://www.unhcr.org/53b2c42c9.pdf. Accessed on April 202021.

${ }^{100}$ General Assembly, A/RES/57/187, 6 February 2003; General Assembly, A/RES/47/105, 16 December 1992.

101 General Assembly, A/RES/42/109, 7 December 1987, para 2.

${ }_{102}$ General Assembly, A/RES/36/125, 14 December 1981, Preamble, para 11.
} 
and rescue mechanisms. ${ }^{103}$ In 2012 the General Assembly also called upon States to create opportunities for resettlement as a durable solution and stressed that resettlement is a strategic tool for the protection of and solutions for refugees. ${ }^{104}$

More importantly, the UN General Assembly on several occasions in its 'Oceans and the Law of the Sea' forums has placed importance on the search and rescue of refugees and the disembarkation process in particular. ${ }^{105}$ It called on the member States to ensure the application of the SAR Convention and to follow its guidelines regarding assistance to persons in distress at sea. ${ }^{106}$ It was also recognised that all States must fulfil their search and rescue responsibilities in accordance with international law. ${ }^{107}$ The General Assembly emphasised that:

in particular, [the need of ] developing States both to increase and improve their search and rescue capabilities, including as appropriate through the establishment of additional rescue coordination centres and regional sub-centres, and to take effective action to address, to the extent feasible, the issue of unseaworthy ships and small craft within their national jurisdiction, and emphasizes in this regard the importance of cooperation for these purposes, including within the framework of the International Convention on Maritime Search and Rescue, $1979 .{ }^{108}$

In 2016 the General Assembly in 'Oceans and the Law of the Sea' forum called upon States to continue their cooperation in developing comprehensive approaches to international migration arrangements. ${ }^{109}$ The Assembly also encouraged the development of capacity building, in particular for the least developed countries and Small Island developing States, to improve aids to navigation and search and rescue services. $^{110}$

In September 2016 the General Assembly adopted the New York Declaration for Refugees and Migrants ${ }^{111}$ which is aimed at developing a global compact for a safe migration regime. The Global Compact for Migration is the first-ever UN global agreement on a common and comprehensive approach to international migration. The Global Compact is non-legally binding. It encompasses 23 objectives for better

\footnotetext{
103 General Assembly, A/RES/67/149, 20 December 2012, para 20; General Assembly, A/RES/68/141, 18 December 2013, para 23; General Assembly, A/RES/ 69/152, 18 December 2014, para 24;

104 General Assembly, A/RES/67/149, 20 December 2012, para 29.

105 General Assembly, A/RES/71/257, 20 February 2017, para 163-165. General Assembly, A/ RES/63/111, 12 February 2009, paras 88-92. General Assembly, A/RES/65/37, 17 March 2011, paras 177-120. General Assembly, A/RES/66/231, 5 April 2012, paras 118-120. General Assembly, A/ RES/61/222, 16 March 2007, para 70.

106 General Assembly, A/RES/69/245, 24 February 2015, para 144; General Assembly, A/RES/70/235, 15 March 2016, para 152.

107 General Assembly, A/RES/69/245, 24 February 2015, para 146. General Assembly, A/RES/70/235, 15 March 2016, para 153.

108 General Assembly, A/RES/70/235, 15 March 2016, para 153.

109 General Assembly, A/RES/69/245, 24 February 2015, para 150.

110 General Assembly, A/RES/71/257, 20 February 2017, para 16.

111 General Assembly, A/RES/71/1, 3 October 2016 (New York Declaration for Refugees and Migrants).
} 
treatment of migrants at local, national, regional and global levels. ${ }^{112}$ In the New York Declaration all 193 member States of the United Nations agreed that international responsibility on forced migration should be carried out more equitably and predictably. The Declaration also assigned the UNHCR to prepare a Comprehensive Refugee Response Framework (CRRF), which will call for greater support to refugees and the countries that host them. ${ }^{113}$

According to the Charter of the United Nations, the Security Council is the primary responsible body for maintaining international peace and security; any decision of the Security Council is binding on its Member States. ${ }^{114}$ In contrast, the General Assembly may discuss any matters within the scope of the UN Charter and make recommendations to the Members of the United Nations or to the Security Council or to both on any such questions or matters. ${ }^{115}$ Article 13(1) of the Charter of United Nations further states that:

The General Assembly shall initiate studies and make recommendations for the purpose of: (a) promoting international co-operation in the political field and encouraging the progressive development of international law and its codification; (b) promoting international co-operation in the economic, social, cultural, educational, and health fields, and assisting in the realization of human rights and fundamental freedoms for all without distinction as to race, sex, language, or religion.

There is no world legislature body. ${ }^{116}$ However, the UN General Assembly is a forum where Member States can express their views, discuss political issues, make recommendations on the development of international law and promote international co-operation in protection of human rights. In doing so, the UN General Assembly resolutions make strong contributions to the development of customary international law. $^{117}$

Even though the decisions of the UN General Assembly are not binding like an international treaty on its Member States, the resolutions do have normative value. The General Assembly resolutions demonstrate the commitments and obligations of the Member States regarding protection of human rights, non-refoulement, refugees at sea and international co-operation in search and rescue operations at sea, all of which indicates positive approaches regarding the commitment to international law.

\footnotetext{
112 Global Compact for Migration. https://refugeesmigrants.un.org/migration-compact. Accessed on April 202021.

113 UNHCR. Towards a Global Compact on Refugees. https://www.unhcr.org/towards-a-global-compa ct-on-refugees.html. Accessed on April 20 2021. UNHCR. Comprehensive Refugee Response Framework. https://www.unhcr.org/comprehensive-refugee-response-framework-crrf.html. Accessed on April 202021

114 Articles 24 and 25, The Charter of United Nations 1945.

115 Article 10, The Charter of United Nations 1945.

116 Schwebel (1979: 301).

117 Kerwin (1983:892), Öberg (2006:879) and Shaw (2008: 1210-1212).
} 


\section{(B) UNHCR Guidelines on Refugees at Sea}

The UNHCR also issues special notes on the principle of non-refoulement. ${ }^{118}$ The UNHCR has notably expressed that the principle of non-refoulement applies not only in respect of the country of origin but of any country where a person has reason to fear persecution. ${ }^{119}$ The UNHCR has also issued special legal considerations on search and rescue operations involving refugees and migrants at sea. ${ }^{120}$ The note sets out a number of legal considerations, including issues arising in the context of cooperation between the range of actors involved in SAR responses.

The Advisory Opinion on the Extraterritorial Application of Non-Refoulement Obligations by the UNHCR asserted that Article 33 of the 1951 Refugee Convention (non-refoulement) applies wherever a State exercises jurisdiction, including at the frontier, on the high seas or on the territory of another State. ${ }^{121}$

The UNHCR has issued the Handbook and Guidelines on Procedures and Criteria for Determining Refugee Status. ${ }^{122}$ It is this study's contention that there is no guidance in the UNHCR Handbook on non-refoulement in the context of refugees at sea. The UNHCR justifies its shortcomings by saying that it is not possible to encompass every situation in which a person may apply for refugee status." ${ }^{123}$ Subsequently, the UNHCR issued the Guidelines on Prima Facie Recognition of Refugee Status to complement the UNHCR Handbook. ${ }^{124}$ In the Guideline, the UNHCR states:

A prima facie approach means the recognition by a State or UNHCR of refugee status on the basis of readily apparent, objective circumstances in the country of origin or, in the case of stateless asylum seekers, their country of former habitual residence. ${ }^{125}$

In the Prima Facie Guidelines UNHCR further states that 'A prima facie approach is particularly suited to situations of large-scale arrivals of refugees', and also 'in relation to groups of similarly situated individuals whose arrival is not on a large-scale,

\footnotetext{
118 UNHCR, Note on the Principle of Non-Refoulement, November $1997<$ https://www.refworld.org/ docid/438c6d972.html > Accessed on April 16, 2021.

119 UNHCR, Note on Non-Refoulement. (EC/SCP/2). 23 August 1977, para $4<$ https://www.unhcr.org/ excom/scip/3ae68ccd10/note-non-refoulement-submitted-high-commissioner.html $>$. Accessed on April $16,2021$.

120 UNHCR, General Legal Considerations: Search-and-Rescue Operations Involving Refugees and Migrants at Sea, November $2017<$ https://www.refworld.org/docid/5a2e9efd4.html > . Accessed on April $16,2021$.

121 UNHCR, Advisory Opinion, supra note 45, paras 24, 26, 32-43.

122 UNHCR, Handbook, supra note 47, para. 220.

123 Ibid. paras. 221 and 223.

124 UNHCR, Guidelines on International Protection No. 11: Prima Facie Recognition of Refugee Status, 24 June 2015, HCR/GIP/15/11<https://www.refworld.org/docid/555c335a4.html>. Accessed on April $16,2021$.

125 Ibid. para. 1.
} 
but who share a readily apparent common risk of harm'. ${ }^{126}$ The Prima Facie Guidelines also emphasis that the prima facie basis of refugees differs from other types of refugee protection. This type of arrangement is taken as an emergency response to large-scale movements of persons who need international protection, and especially the non-refoulement and international human rights that are ensured to the vulnerable group of people. ${ }^{127}$

Later, the UNHCR endorsed the Guidelines on Temporary Protection or Stay Arrangements, ${ }^{128}$ in which maritime arrival and boat refugee issues are given particular emphasis, and ensured for temporary protection, disembarkation and rescue at sea scenarios for them. The guidelines recognise four circumstances in which temporary protection or stay arrangements are a particularly suitable response: (i) large-scale arrivals of asylum seekers or other similar humanitarian crises; (ii) complex or mixed cross-border population movements, including boat arrivals and rescue-at-sea scenarios; (iii) fluid or transitional contexts; or (iv) other exceptional and temporary conditions. ${ }^{129}$

In 2015 the UNHCR, IMO and International Chambers of Shipping jointly adopted 'Rescue at Sea: A Guide to Principles and Practice as Applied to Migrants and Refugees. ${ }^{130}$ The guide is provided for masters, ship owners, government authorities and other interested parties involved in rescue at sea situations. It provides guidance to ship masters, governments and rescue coordination centres (RCCS) on relevant legal provisions and on practical procedures to ensure the prompt disembarkation of survivors of rescue operations, and measures to meet their specific needs, particularly in the case of refugees and asylum-seekers at sea. ${ }^{131}$

\section{(C) ExCom Conclusions and Protection of Refugee Seekers at Sea}

The UNHCR and ExCom have been contributing as an 'absolute hegemonic' body in refugee protection all over the world since their establishment. ${ }^{132}$ The ExCom is a forum of States who are interested in, and devoted to, solving refugee problems. ${ }^{133}$ The global refugee issues are 'discussed and devised' in ExCom, so that ExCom

\footnotetext{
126 Ibid. paras. 9-10.

127 Ibid. para. 26.

128 UNHCR, Guidelines on Temporary Protection or Stay Arrangements, February $2014<$ https://www. refworld.org/docid/52fba2404.html >. Accessed on April 16, 2021.

129 Ibid., para. 9.

${ }^{130}$ UNHCR, IMO and International Chambers of Shipping, 'Rescue at Sea: A Guide to Principles and Practice as Applied to Migrants and Refugees' (January 2015) < https://www.refworld.org/docid/54b36 5554.html > Accessed on April 16, 2021.

131 Ibid.

132 Ben-Nun (2017: 17).

133 UNHCR, 'Background on the Executive Committee', 01 July $2001<$ https://www.unhcr.org/en-au/ excom/announce/3b4f09faa/background-executive-committee.html > Accessed on April 16, 2021.

In 2018, 102 states are ExCom members. 'UNHCR - ExCom membership by Date of Admission of Members' < https://www.unhcr.org/excom/announce/40112e984/excom-membership-date-admissionmembers.html $>$ Accessed on April 16, 2021.
} 
becomes a 'playing field' where governments and other institutions and NGOs interact. ${ }^{134}$ The ExCom decisions have been considered the opinio juris of the participating states. ${ }^{135}$

ExCom has adopted several conclusions on non-refoulement obligations. ${ }^{136}$ ExCom Conclusion No. 22 regarding the 'protection of asylum-seekers in situations of large-scale influx' especially emphasises non-refoulement; it states that 'in all cases the fundamental principle of non-refoulement-including non-rejection at the frontier-must be scrupulously observed'. ${ }^{137}$ ExCom Conclusion No. 82 (1997) repeats the safeguarding of asylum as 'the need to admit refugees into the territories of states, which includes no rejection at frontiers without fair and effective procedures for determining status and protection needs' ${ }^{138}$ ExCom expresses its great concerns that:

refugee protection is seriously jeopardized in some States by expulsion and refoulement of refugees or by measures which do not recognize the special situation of refugees and called on all States to refrain from taking such measures and in particular from returning or expelling refugees contrary to fundamental prohibitions against these practices. ${ }^{139}$

The Executive Committee of UNHCR has called to the states 'to scrupulously respect the principle of non-refoulement' ${ }^{140}$ Most importantly, ExCom has on many occasions called for protection and rescue of asylum seekers at sea. ${ }^{141}$ ExCom members stated they were 'deeply concerned at the fate of asylum-seekers who had left their country in small boats and were in need of rescue or admission to a country of first asylum and eventually of final settlement'. ${ }^{142}$ They also 'called upon all States to ensure that masters of vessels sailing under their flag scrupulously observed the established rules regarding rescue at sea, and to take all necessary actions to rescue refugees and displaced persons leaving their country of origin on boats in order to

\footnotetext{
134 Gilad Ben-Nun (2017:16).

135 Lehmann (2011: 743).

136 ExCom Conclusion No. 1 (1975); ExCom Conclusion No. 17 (1980); ExCom Conclusion No. 19 (1980); ExCom No. 22 (1981); ExCom Conclusion No. 29 (1983); ExCom Conclusion No. 55 (1989); ExCom Conclusion No. 99 (2004); ExCom Conclusion No. 103 (2005); ExCom Conclusion No. 108 (2008).

137 ExCom Conclusion No. 22 (1981)_Protection of Asylum-Seekers in Situations of Large-Scale Influx,

Part II (Measures of protection) A, para 2.

138 ExCom Conclusion No. 82 (1997)—Conclusion on Safeguarding Asylum, para d, (iii).

139 ExCom Conclusion No. 55 (1989), para (d).

140 ExCom Conclusion No. 108 (2008), para (a).

141 ExCom Conclusion No. 2 (1976); ExCom Conclusion No. 14 (1979); ExCom Conclusion No. 15 (1979) ExCom Conclusion No. 20 (1980)_Protection of Asylum-Seekers at Sea; ExCom Conclusion No. 21 (1981); ExCom Conclusion No. 23 (1981)—Problems Related to the Rescue of Asylum-Seekers in Distress at Sea; ExCom Conclusion No. 25 (1982); ExCom Conclusion No. 33 (1984); ExCom Conclusion No. 38 (1985)—Rescue of Asylum-Seekers in Distress at Sea; ExCom Conclusion No. 97 (2003).

142 ExCom Conclusion No. 2 (1976), para (f).
} 
seek asylum and who are in distress' ${ }^{143}$ In Conclusion No. 15 of ExCom, importance was given to refugees without an asylum country, stating 'it is the humanitarian obligation of all coastal States to allow vessels in distress to seek haven in their waters and to grant asylum, or at least temporary refuge, to persons on board wishing to seek asylum'. ${ }^{144}$

ExCom has focused on the problems related to rescue of asylum seekers in distress at sea, and issued the reminder that 'there is a fundamental obligation under international law for ships' masters to rescue any persons in distress at sea, including asylum seekers ... States should take all appropriate measures to ensure that masters of vessels observe this obligation strictly'. ${ }^{145}$

The ExCom Committee expressed its concern that refugee protection is a complex issue under international law, and this has become more challenging due to security problems, human trafficking and smuggling. However, it recalled that it is the 'the duty of States and shipmasters to ensure the safety of life at sea and to come to the aid of those in distress or in danger of being lost at sea' ${ }^{146}$ ExCom has recommended that interception measures be guided by special considerations in order to ensure adequate treatment of asylum seekers and refugees ${ }^{147}$; the principle of nonrefoulement has to be followed all the time and if intercepted persons need international protection they should have access to durable solutions ${ }^{148}$; and special care should be given to women, children and other vulnerable groups of people. ${ }^{149}$

\section{IMO Guidelines and Rescue at Sea ${ }^{150}$}

In the aftermath of the Tampa incident of 2001, ${ }^{151}$ the International Maritime Organization (IMO) adopted Resolution A.920(22) and reviewed the safety measures and procedures for the treatment of persons rescued at sea. Thereafter, the International Convention for the Safety of Life at Sea 1974 (SOLAS), ${ }^{152}$ and the International

\footnotetext{
143 ExCom Conclusion No. 14 (1979), para (d).

144 ExCom Conclusion No. 15 (1979)_Refugees without an Asylum Country, para (c).

145 ExCom Conclusion No. 23 (1981)_Problems Related to the Rescue of Asylum-Seekers, para.1.

146 ExCom Conclusion No. 97 (2003) —Conclusion on Protection Safeguards in Interception Measures.

147 Ibid., para (a).

148 Ibid., para (a)(iv).

149 Ibid.

150 A specialized agency of the United Nations, the IMO is the global standard-setting authority for the safety, security and environmental performance of international shipping. The overall objectives of IMO are safe, secure and efficient shipping on clean oceans. IMO, What It Is, online: IMO < http://www.imo. org/en/About/Documents/What\%20it\%20is\%200ct\%202013_Web.pdf > .

151 Willheim (2003: 159).

152 International Convention for the Safety of Life at Sea (SOLAS), adopted on 1 November 1974, 1184 United Nations Treaty Series 2. See particularly, SOLAS 1974, Chapter V (Safety of Navigation).
} 
Convention on Maritime Search and Rescue 1979 (SAR) were amended, ${ }^{153}$ and the Guidelines on the Treatment of Persons Rescued at Sea were adopted. ${ }^{154}$

The aim of the Guidelines is to provide guidance to governments and to shipmasters in relation to humanitarian obligations and obligations under the relevant international law relating to treatment of persons rescued at sea. ${ }^{155}$ The Guidelines state that all persons in distress at sea should be assisted without delay. ${ }^{156}$ It also emphasises the establishment of Rescue Coordination Centres (RCC). ${ }^{157}$

The Guidelines principally relate to and supplement the 2004 amendments of the SAR and SOLAS Conventions. The Guidelines outline a 'place of safety' as a place where rescue operations are to be terminated, where a rescued person's safety of life is no longer endangered and basic needs (food, shelter and medical needs) could be available. The Guidelines also place emphasis on avoiding the disembarkation of refugees in territories where there is risk of persecution. The Guidelines recommend that the responsibility to provide a place of safety, or to ensure a place of safety for the rescued persons, mainly falls on the government of the SAR region, from which the person is rescued. ${ }^{158}$

The IMO also adopted the 'Principles Relating to Administrative Procedures for Disembarking Persons Rescued at Sea' ${ }^{159}$ These Principles seek to harmonise the various procedures for disembarking persons rescued at sea in a more efficient and predictable way. Five essential principles are identified and recommended for incorporation into relevant State administrative procedures. ${ }^{160}$ (1) The coastal States should ensure coordination of the search and rescue (SAR) service for the

\footnotetext{
153 International Convention on Maritime Search and Rescue (SAR), opened for signature 27 April 1979, 1403 UNTS 118. See particularly, SAR 1979, Annex to the Convention.

154 IMO, Guidelines on the Treatment of Persons Rescued at Sea, Resolution MSC. 167(78), MSC 78/26/Add.2, Annex 34, adopted by the Maritime Safety Committee, 20 May 2004.

155 Purpose of the Guidelines on the Treatment of Persons Rescued at Sea, Annex 34, para 1.1.

156 Ibid., para. 3.1.

157 Ibid., para. 6.

158 UNHCR, Rescue at Sea, Stowaways and Maritime Interception: Selected Reference Materials (2nd edition, Dec. 2011) < https://www.unhcr.org/4ee1d32b9.pdf>63, Accessed on April 16, 2021.

159 IMO, 'Principles Relating to Administrative Procedures for Disembarking Persons Rescued at Sea', FAL.3/Circ.194, 22 January 2009, Ref. T3/2.02<http://www.imo.org/en/OurWork/Facilitation/Docum ents/FAL.3\%20Circ.194.pdf>. Accessed on April 16, 2021.

160 Ibid, para 2.1-2.5. The five essential principles are: (1) The coastal states should ensure coordination the search and rescue (SAR) service for the disembarkation of persons rescued at sea. (2) Screening and status assessment of rescued persons be carried out after disembarkation to a place of safety, and if a rescued person expresses a wish to apply for asylum, great consideration must be given to the security of the asylum seeker. (3) All parties involved in a rescue operation should cooperate in order to ensure that disembarkation of the persons rescued is carried out swiftly, and if disembarkation from the rescuing ship cannot be arranged swiftly elsewhere, the government responsible for the SAR area should accept the disembarkation of the persons rescued. (4) All parties involved should cooperate with the government of the area where the persons rescued have been disembarked to facilitate the return or repatriation of the persons rescued. Rescued asylum seekers should be referred to the responsible asylum authority for an examination of their asylum request. (5) International protection principles as set out in international instruments should be followed (specially pointed: Article 33(1) of the 1951 Refugee Convention; Article 3(1) of the 1984 Convention against Torture and Other Cruel, Inhuman or Degrading Treatment or Punishment).
} 
disembarkation of persons rescued at sea. (2) Screening and status assessment of rescued persons will be carried out after disembarkation to a place of safety, and if a rescued person expresses a wish to apply for asylum, great consideration must be given to the security of the asylum seeker. (3) All parties involved in a rescue operation should cooperate in order to ensure that disembarkation of the persons rescued is carried out swiftly, and if disembarkation from the rescuing ship cannot be arranged swiftly elsewhere, the government responsible for the SAR area should accept the disembarkation of the persons rescued. (4) All parties involved should cooperate with the government of the area where the persons rescued have been disembarked to facilitate the return or repatriation of the persons rescued. Rescued asylum seekers should be referred to the responsible asylum authority for an examination of their asylum request. (5) International protection principles as set out in international instruments should be followed (in particular Article 33[1] of the 1951 Refugee Convention; Article 3[1] of the 1984 Convention against Torture and Other Cruel, Inhuman or Degrading Treatment or Punishment). Although these (five) principles are not binding, they have significance in practice. In fact, the 'Principles Relating to Administrative Procedures for Disembarking Persons Rescued at Sea' are important because for the first time a strategy for cooperation in rescue operation and disembarkation is provided by the international community, specifically for asylum seekers at sea.

In conclusion, it is evident from the above examination that the UN General Assembly, UNHCR, ExCom and IMO are determined to protect refugees and distressed person at sea, and to this end they have adopted numerous notes, guidelines, principles, recommendations, suggestions and resolutions. These materials have called on member States to lift their international commitments. The IMO Guidelines on the Treatment of Persons Rescued at Sea and 'Principles Relating to Administrative Procedures for Disembarking Persons Rescued at Sea' in particular suggest some unique directions for the protection of people rescued at sea. These soft laws endeavour to minimise the gaps in law. They focus on the complex issues and ask States to fulfil their commitments. This provides guidance for State practice and State policy making.

\section{Evaluation of the Soft Law Regarding Refugee Protection at Sea}

International refugee law provides mechanisms to protect refugees. Refugee law specially provides that refugees are allowed without valid documentation ${ }^{161}$; and prohibits expulsion or return (non-refoulement obligation) to the frontiers of territories where the refugee's life or freedom would be threatened. ${ }^{162}$ However, to claim refugee status, the applicant must present themselves on the territory of the State. Also, as already noted, it is not clear, according to the plain meaning of the 1951 Refugee

\footnotetext{
161 Article 31(1) of the 1951 Refugee Convention states that the Contracting States shall not impose penalties, on account of unlawfully or illegal entry or presence of refugees into their territory.

162 Article 33(1) of the 1951 Refugee Convention.
} 
Convention, whether the Convention is applicable at high sea or if it has extraterritorial effect. Moreover, international refugee law only deals with refugee protection; it does not deal with rescuing at sea and prevention of drowning. ${ }^{163}$ Accordingly, if refugees arrive by sea, or are in distress at sea, the present international law does not provide any clear obligation to the States with regard to boat refugees. However, amendment of a treaty is a complex issue in international law as it involves practical and political difficulties. ${ }^{164}$ Therefore, to overcome the challenges of boat refugees and refugees at sea, soft laws have been developed to ensure the safety and disembarkation of refugees. It is a very positive move that international communities are concerned about refugees at sea, especially, the non-refoulement obligation, and thus have adopted numerous soft laws to overcome the shortcomings of the refugee protection regime at sea. However, a key concern of the soft laws is, even though they provide rescuing and refugee protection at sea and disembarkation of boat refugees, adopted by ExCom, UNHCR, UN General Assembly and IMO, the soft laws are not binding as treaty law. Therefore, the next section revisits the soft laws within the modern view of international law.

In the traditional view, a State is sovereign within its jurisdiction. Sovereignty is one of the central notions in international law. Sovereignty power is the fundamental power of a State to exercise its powers over its territory. ${ }^{165}$ However, under modern international law, certain values are considered not only territorial but also global and international (e.g. human rights, international peace and security, environmental issues). ${ }^{166}$ The concept of absolute 'sovereignty' of a State changes once it signs human rights and environmental treaties. Thus, the concept of 'absolute sovereignty' has become 'restricted sovereignty'. ${ }^{167}$ In 1923 the Permanent Court of International Justice in an Advisory Opinion (Nationality Decrees Issued in Tunis and Morocco) declared that sovereignty is not solely the matter of a State but depends upon 'international relations'. ${ }^{168}$ The Court further states that the right of a State to use its discretion is restricted by obligations which it has undertaken towards other States. ${ }^{169}$ In this context James Hathaway states that 'International human rights law is fundamentally a means of delimiting State sovereignty'. ${ }^{170}$ As a consequence, the concept of sovereignty has lost its normative or descriptive nature under modern international law, and States are bound by formal and informal rules and regimes of international law which ensures human rights, security and welfare to all human being. ${ }^{171}$

\footnotetext{
163 Mann, supra note 65, 607.

164 Article 40 (Amendment of multilateral treaties), 1969 Vienna Convention on the Law of Treaties. See also, Bowman (1995: 540).

165 Dixon, McCorquodale, and Williams (2016: 244).

166 Hassan (2015: 139).

167 Ibid., 139-140.

168 Nationality Decrees Issued in Tunis and Morocco, Advisory Opinion No. 4, 7 February 1923, P.C.I.J., at 24.

169 Ibid.

170 Hathaway (1991: 113).

${ }^{171}$ Koskenniemi (2011: 62-63).
} 
There is also a connection between soft law, customary law and treaty law. Soft law or no-binding norm is a voluntary commitment of a State to international obligation. Over the time, State practice of soft law becomes customary law and when the customary law is codified into the written form then it becomes legally binding treaty law. Thus, practice of soft law/ non-binding instruments contributes to the development of international law. In this context, the Geneva Convention on the High Seas 1958 is a great example. The 1958 Geneva Convention states that it 'codify the rules of international law relating to the high seas' (Preamble) and it recognises the 'general principles of international law' as sources of law for the high seas (Article 2). The soft law also plays an important role in international law. The soft laws/non-binding instruments are examples of State practice which provide evidence of opinio juris in support of a customary rule. In this context, the International Court of Justice's (ICJ) views on the Nuclear Weapons Advisory Opinion, ${ }^{172}$ and the Western Sahara Advisory Opinion ${ }^{173}$ are most notable examples.

On the other hand, the ASEAN ${ }^{174}$ States adopted the ASEAN Human Rights Declaration in 2012. ${ }^{175}$ Article 16 of the ASEAN Human Rights Declaration states that 'Every person has the right to seek and receive asylum in another State in accordance with the laws of such State and applicable international agreements.' However, the ASEAN is based on the principle of 'non-interference.' In particular, Article 2(e) of the ASEAN Charter provides that ASEAN and its Member States shall act in 'non-interference in the internal affairs of ASEAN Member States.' As a result, in practice, ASEAN states are reluctant to deal openly with the refugee issue in their region. Thus, the ASEAN States, Thailand, Malaysia, Indonesia, Myanmar other member States never emphasize refugee matters in their round-table agenda; Rohingyan issues are always neglected due to the non-interference policy. Moreover, while refugee law is absent in Bangladesh, refugees are vulnerable in law and policy there. ${ }^{176}$ Until Bangladesh agrees to, and comes under international refugee law, refugees will not receive an international standard of protection in Bangladesh, especially the non-refoulement to the boat refugees.

Clearly, as this paper shows, there are significant, ongoing challenges in international law regarding the protection of boat refugees. However, even though the coastal States of the Bay of Bengal region are non-parties to international refugee law, these States consent to support and follow international rules, resolutions and guidance that are adopted under the UN General Assembly, UNHCR, ExCom and IMO. As a result, it is expected that as a general principle of international law, the States should respect their international commitments and protect the boat refugees.

\footnotetext{
172 Legality of the Threat or Use of Nuclear Weapons, Advisory Opinion, ICJ GL No 95, [1996] ICJ Rep 226.

173 Western Sahara, Advisory Opinion, ICJ GL No 61, [1975] ICJ Rep 12.

174 Association of Southeast Asian Nations (ASEAN). Indonesia, Malaysia, the Philippines, Singapore, Thailand, Brunei, Vietnam, Laos, Myanmar (Burma) and Cambodia are members of it. ASEAN is regulated by the ASEAN Charter. ASEAN Charter was signed at the 13th ASEAN Summit, Singapore, 20 November 2007.

175 The ASEAN Human Rights Declaration 2012, 21st ASEAN Summit Cambodia, 18 November 2012.

176 Al Imran and Nannu (2014: 226-253).
} 
In this context, the States should allow disembarkation, ensure sufficient search and rescue operations, and respect the non-refoulement principle for refugees at sea.

\section{Conclusion}

Rohingya people are a highly vulnerable ethnic group in Myanmar, their usual country of residence. Discriminatory laws and policies as well as severe persecution have forced them to leave their country. Due to the geographic nature of Rakhine State of Myanmar, the journey is made either by crossing the border or by sea. However, due to non-accreditation to the international refugee law by neighbouring States, refugees are not welcome. Boat refugees in particular face push back and interception at sea policies. In reality, the Rohingya boat refugees face various jeopardies-persecution in Myanmar, a lack of welcome by the neighbouring States, and push back to the sea.

Although the above examination suggests that the international law for the protection of refugees has progressed, significant challenges remain. In this respect, the UNHCR, ExCom body, UN General Assembly and IMO are very concerned to protect refugees and distressed persons at sea, and to this end they have adopted numerous notes, guidelines, principles, recommendations, suggestions and resolutions. These materials have called on member States to lift their international commitments. In particular, these soft laws suggest that in all cases, the non-refoulement commitment - the fundamental principle of refugee protection-must be carefully observed. The IMO Guidelines on the Treatment of Persons Rescued at Sea and 'Principles Relating to Administrative Procedures for Disembarking Persons Rescued at Sea' also suggest some unique directions for the protection of people rescued at sea. These soft laws try to minimise or fill or close the gaps in international law. They focus on the complex issues and ask States to fulfil their commitments. This provides guidance for State policy making. However, the main concern of this 'soft law' is its non-binding nature, which is not considered as treaty law. Nevertheless, the soft law reminds the States-what should be done in a particular situation. If a State expresses its consent on any international issue or resolution, then it is expected that the State should act on it with good faith. Moreover, under modern international law, States have an obligation to respect and ensure human rights to all people within their jurisdiction including boat refugees. Therefore, this paper suggests that even though there are gaps in international law regarding the protection of boat refugees, nonetheless, a State cannot totally deny its international obligation. It is expected that under the soft laws or the general principle of international law, a State is responsible to protect boat refugees. Accordingly, the coastal States of the Bay of Bengal region have obligations under international law to protect the boat refugees and respect the non-refoulement obligation. 


\section{References}

Adelman, Howard (ed). 2008. Protracted Displacement in Asia: No Place to Call Home. Ashgate Publishing.

Imran, Al., Hassan Faruk, and Md. Nannu Miah. 2014. The Rohingya refugees in Bangladesh: A vulnerable group in law and policy. Journal of Studies in Social Sciences 8 (2): 226-253.

Alam, Jobair. 2018. The Rohingya of Myanmar: Theoretical significance of the minority status. Asian Ethnicity 19 (2): 180-210.

Alam, Jobair. 2019. The current Rohingya crisis in Myanmar in historical perspective. Journal of Muslim Minority Affairs 39 (1): 1-25.

Alam, Jobair. 2021. The status and rights of the Rohingya as refugees under international refugee law: Challenges for a durable solution. Journal of Immigrant and Refugee Studies 19 (2): 128-141.

Basaran, Tugba. 2014. Saving lives at Sea: Security, law and adverse effects. European Journal of Migration and Law 16: 365-387.

Ben-Nun, Gilad. 2017. The expansion of international space: UNHCR's establishment of its executive committee ("ExCom"). Refugee Survey Quarterly 36: 1-19.

Bowman, M.J. 1995. The multilateral treaty amendment process: A case study. The International and Comparative Law Quarterly 44 (3): 540-559.

Boyle, A.E. 1999. Some reflections on the relationship of treaties and soft law. International and Comparative Law Quarterly 48 (4): 901-913.

Chesterman, Simon, David M. Malone, Santiago Villalpando and Alexandra Ivanovic (eds.). 2019. The Oxford Handbook of United Nations Treaties. Oxford University Press.

Chetail, Vincent. 2012. Sources of international migration law. In Foundations of international migration law, ed. B. Opeskin, R. Perruchoud, and J. Redpath-Cross, 56-92. Cambridge: Cambridge University Press.

Coppens, Jasmine, and Eduard Somers. 2010. Towards new rules on disembarkation of persons rescued at sea? The International Journal of Marine and Coastal Law 25 (3): 377-403.

Davies, Sara. 2006a. Saving refugees or saving borders? Southeast Asian states and the Indochinese refugee crisis. Global Change, Peace and Security 18 (1): 3-24.

Davies, Sara. 2006b. The Asian rejection? International refugee law in Asia. Australian Journal of Politics and History 52 (4): 562-575.

del Castillo, Teresa, and Fajardo . 2014. Soft Law and the law of the sea its presence in the UNCLOS. In The contribution of the United Nations convention on the law of the sea to the good governance of the seas and oceans, vol. 1, ed. José Manuel Sobrino. Heredia, 65-78. Spain: Editoriale Scientifica.

Dixon, Martin. 2016. Robert McCorquodale, and Sarah Williams, Cases and Materials on International Law. Oxford: Oxford University Press.

Dorr, Oliver, and Kirsten Schmalenbach, eds. 2018. Vienna convention on the law of treaties: A commentary. Berlin: Springer.

Elias, Olufemi, and Chin Lim. 1997. General principles of law", "soft" law and the identification of international law. Netherlands Yearbook of International Law 28: 3-49.

Fox, Peter D. 2010. International Asylum and boat people: The Tampa Affair and Australia's "Pacific solution. Maryland Journal of International Law 25 (1): 356-373.

Gammeltoft-Hansen, Thomas. 2014. Extraterritorial migration control and the reach of human rights. In Research handbook on international law and migration, ed. Vincent Chetail and Céline. Bauloz, 113-131. New York: Edward Elgar Publishing.

Ghráinne, B Ní. 2015. Left to die at Sea: State responsibility for the May 2015 Thai, Indonesian, and Malaysian Pushback Operations. Irish Yearbook of International Law 10: 109-131.

Giuffré, Mariagiulia. 2012. State responsibility beyond borders: What legal basis for Italy's push-backs to Libya? International Journal of Refugee Law 24 (4): 692-734.

Goodwin-Gill, Guy, and Jane McAdam. 2007. The Refugee in international law, 3rd ed. Oxford: Oxford University Press.

Guzman, Andrew T., and Timothy L. Meyer. 2010. International soft law. Journal of Legal Analysis 2 (1): 171-225.

Haque, Md.M. 2017. Rohingya ethnic muslim minority and the 1982 Citizenship law in Burma. Journal of Muslim Minority Affairs 37 (4): 454-469.

Harrison, James. 2011. Making the law of the Sea: A study in the development of international law. Cambridge: Cambridge University Press. 
Hassan, Daud, and Hassan Al Imran. 2020. Boat refugees, international law and Australia's commitment: An analysis. Journal of Maritime Law and Commerce 51 (3): 187-241.

Hassan, Daud. 2015. Territorial sovereignty and state responsibility: An environmental perspective. Environmental Policy and Law 45 (3-4): 139-145.

Hathaway, James, and Michelle Foster. 2014. The law of refugee status, 2nd ed. Cambridge: Cambridge University Press.

Hathaway, James. 1991. Reconceiving refugee law as human rights protection. Journal of Refugee Studies 4 (2): 113-131.

Kalin, Walter, Martina Caroni \& Lukas Heim. 2011. Article 33, Para 1, (Prohibition of Expulsion to Return ('Refoulement'). In Andreas Zimmermann (ed), The 1951 Convention Relating to the Status of the Refugees and its 1967 Protocol: A Commentary. Oxford University Press: 1327-1395.

Kerwin, Gregory J. 1983. The role of United Nations general assembly resolutions in determining principles of international law in United States Courts. Duke Law Journal 1983: 876-899.

Kolb, Robert. 2016. The law of treaties: An introduction. New York: Edward Elgar Publishing.

Koskenniemi, Martti. 2011. What use for sovereignty today? Asian Journal of International Law 1 (1): 61-70.

Lansakara, Francis. 2014-2015. Rescue of Migrants at Sea under Maritime Law Regime. The Indian Society of International Law (ISIL) Year Book of International Humanitarian and Refugee Law 14: $288-295$.

Legomsky, Stephen H. 2006. The USA and the Caribbean interdiction program. International Journal of Refugee Law 18 (3-4): 677-695.

Lehmann, Julian M. 2011. Rights at the frontier: Border control and human rights protection of irregular international migrants. Goettingen Journal of International Law 3 (2): 733-775.

Malanczuk, Peter. 1997. Modern introduction to international law. New York: Routledge.

Mann, Itamar. 2018. Maritime legal black holes: Migration and rightlessness in international law. European Journal of International Law 29 (2): 347-372.

Mann, Itamar. 2020. The right to perform rescue at Sea: jurisprudence and drowning. German Law Journal 21: 598-620.

Öberg, Marko Divac. 2006. The Legal effects of resolutions of the UN security council and general assembly in the jurisprudence of the ICJ. The European Journal of International Law 16 (5): 879-906.

Papastavridis, Efthymios D. 2014. Is there a right to be rescued at sea? A skeptical view. Questions of International Law (QIL) 4: 17-32.

Parashar, Archana, and Jobair Alam. 2019. The national laws of Myanmar: Making of statelessness for the Rohingya. International Migration 57 (1): 94-108.

Proelss, Alexander. 2008. Rescue at Sea revisited: What obligations exist towards refugees? Scandinavian Institute of Maritime Law Yearbook (SIMPLY) 376: 1-39.

Pugash, James. 1977. The dilemma of the sea refugee: Rescue without refuge. Harvard International Law Journal 18 (3): 577-604.

Schwebel, Stephen M. 1979. The effect of resolutions of the U.N. General assembly on customary international law. Proceedings of the American Society of International Law Annual Meeting 73: 301-309.

Shaw, Malcolm. 2008. International law, 6th ed. Cambridge: Cambridge University Press.

Skogly, Sigrun. 2006. Beyond national borders: States' human rights obligations in international cooperation. Cambridge: Intersentia.

Southwick, Katherine. 2015. Preventing mass atrocities against the stateless Rohingya in Myanmar: A call for solutions. Journal of International Affairs 68 (2): 137-157.

Stoyanova, Vladislava. 2008. The principle of non-refoulement and the right of asylum-seekers to enter state Territory. Interdisciplinary Journal of Human Rights Law 3 (1): 1-11.

Trevisanut, Seline. 2008. The principle of non-refoulement at sea and the effectiveness of asylum protection. Max Planck Yearbook of United Nations Law 12: 205-246.

Conventions/International Instruments/Legislation/Resolution

1951 Convention Relating to the Status of Refugees, 189 UNTS 137 (entered into force 22 April 1954).

1967 Protocol Relating to the Status of Refugees, 606 UNTS 267(entered into force 4 October 1967).

1969 Vienna Convention on the Law of Treaties, 1155 U.N.T.S. 331 (entered into force 27 January 1980).

Burma Citizenship Law, 15 October 1982 (1982 Citizenship Law)

Charter of the United Nations, 24 October 1945, 1 UNTS XVI. 
ICJ, Legal Consequences of the Construction of a Wall in the Occupied Palestinian Territory, Advisory Opinion, I. C. J. Reports 2004.

IMO, 'Principles Relating to Administrative Procedures for Disembarking Persons Rescued at Sea', FAL.3/Circ.194, 22 January 2009, Ref. T3/2.02

IMO, Guidelines on the Treatment of Persons Rescued at Sea, Resolution MSC. 167(78), MSC 78/26/ Add.2, Annex 34 (adopted by the Maritime Safety Committee, 20 May 2004).

International Convention for the Safety of Life at Sea (SOLAS), 1184 United Nations Treaty Series 2 (entered into force 25 May 1980).

International Convention on Maritime Search and Rescue (SAR), 1403 UNTS 118 (entered into force 22 June 1985).

International Covenant on Economic, Social and Cultural Rights, 16 December 1966, United Nations, Treaty Series, Vol. 993, 3 (entered into force: 3 January 1976).

The ASEAN Charter, signed at the 13th ASEAN Summit, Singapore, 20 November 2007.

The ASEAN Human Rights Declaration 2012, accepted in the 21st ASEAN Summit, Phnom Penh, Cambodia, 18 November 2012.

The Statute of the International Court of Justice 1945, 18th April 1946, 33 UNTS 993 (entered into force 24 October 1945).

United Nations Convention on the Law of the Sea, 1833 UNTS 396 (entered into force 16 November 1994).

\section{Research/Reports/News Sources}

UN Rights Chief Urges Bangladesh to Accept Rohingya Boats. 27 April 2020. Aljazeera. https://www. aljazeera.com/news/2020/04/rights-chief-urges-bangladesh-accept-rohingya-boats-2004271424 38774.html. Accessed on 20 April 2021.

Bangladesh: 'Not a Single Rohingya Will be Allowed to Enter'. 23 April 2020. Radio Free Asia. https:// www.rfa.org/english/news/myanmar/bangladesh-rohingya-04232020195727.html. Accessed on 20 April 2021.

Allard K. Lowenstein International Human Rights Clinic (Yale Law School). 2015. Persecution of the Rohingya Muslims: Is Genocide Occurring in Myanmar's Rakhine State? A Legal Analysis (Research Report). https://law.yale.edu/sites/default/files/documents/pdf/Clinics/fortifyrights.pdf. Accessed on 20 April 2021.

United Nations Human Rights Council. Independent International Fact-Finding Mission on Myanmar. https://www.ohchr.org/en/hrbodies/hrc/myanmarffm/pages/index.aspx. Accessed on 20 April 2021

Myanmar's Genocide Against Rohingya Not Over, Says Rights Group. 24 Nov. 2020. The Guardian. https://www.theguardian.com/world/2020/nov/23/myanmar-is-still-committing-genocide-againstrohingya-says-rights-group. Accessed on 20 April 2021.

Grahl-Madsen, Atle. 1997. Commentary of the Refugee Convention 1951 (Articles 2-11, 13-37). UNHCR, Department of International Protection: 1-155. https://www.refworld.org/docid/4785e e9d2.html. Accessed on 20 April 2021.

Global Compact for Migration <https://refugeesmigrants.un.org/migration-compact> Accessed on 20 April 2021.

UNHCR, IMO and International Chambers of Shipping. January 2015. Rescue at Sea: A Guide to Principles and Practice as Applied to Migrants and Refugees. https://www.refworld.org/docid/54b365554. html. Accessed on 20 April 2021.

Human Rights Watch. 13 January 2015. Burma: Amend Biased Citizenship Law 1982 Act: Fuels Repression, Deprives Rohingya Muslims of Basic Rights. https://www.hrw.org/news/2015/01/13/ burmaamend-biased-citizenship-law. Accessed on 20 April 2021.

Amnesty International. 26 September 2017. Who Are the Rohingya and What is Happening in Myanmar? https://www.amnesty.org.au/who-are-the-rohingya-refugees. Accessed on 20 April 2021.

ICJ. 11 November 2019. The Republic of the Gambia institutes proceedings against the Republic of the Union of Myanmar and asks the Court to indicate provisional measures' (Press Release, No. 2019/47). https://www.icj-cij.org/en/case/178. Accessed on 20 April 2021.

ICJ. 23 January 2020. Application of the Convention on the Prevention and Punishment of the Crime of Genocide (The Gambia v Myanmar). Order. https://www.icj-cij.org/en/case/178. Accessed on 20 April 2021. 
Human Rights Watch. 18 April 2020. Malaysia: Allow Rohingya Refugees Ashore. https://www.hrw.org/ news/2020/04/18/malaysia-allow-rohingya-refugees-ashore. Accessed on 20 April 2021.

Human Rights Watch. 25 April 2020. Bangladesh: Rohingya Refugees Stranded at Sea: Allow Ashore Hundreds at Risk of Starvation, Provide Health Care. https://www.hrw.org/news/2020/04/25/bangl adesh-rohingya-refugees-stranded-sea. Accessed on 20 April 2021.

Faisal Mahmud. 25 April 2020. Rohingya Stranded at Sea, Bangladesh Says Not Its Responsibility. Aljazeera. https://www.aljazeera.com/news/2020/04/rohingya-stranded-sea-bangladesh-responsibility200425082607464.html. Accessed on 20 April 2021.

Maurice Stierl, 13 May 2020. Migration: How Europe is using Coronavirus to reinforce its hostile environment in the Mediterranean. The Conversation. https://theconversation.com/migration-howeurope-is-using-coronavirus-to-reinforce-its-hostile-environment-in-the-mediterranean-137840. Accessed on 20 April 2021.

Human Rights Watch. 12 June 2020. Malaysia/Thailand: Allow Rohingya Refugees Ashore, End Pushbacks, Grant Access to Aid and Asylum. https://www.hrw.org/news/2020/06/12/malaysia/thailandallow-rohingya-refugees-ashore. Accessed on 20 April 2021.

Amnesty International. 6 August 2020. Trinidad and Tobago: Deportation of 165 Venezuelans Violates International Law. https://www.amnesty.org/en/latest/news/2020/08/trinidad-tobago-deportation165-venezuelans-violates-international-law/. Accessed on 20 April 2021.

James Bickerton. 8 August 2020. Britain Could Copy Australia and Start 'Pushing Back' Migrant Boats After Record Numbers,' Expressonline: Express https://www.express.co.uk/news/uk/1320231/ Immigration-news-migrant-boats-border-force-refugees-Nigel-Farage. Accessed on 20 April 2021.

Benjamin Bathke. 6 October 2020. Europe's Pushback of Migrants 'Shameful': UN Refugee Chief. Info Migrants. https://www.infomigrants.net/en/post/27757/europe-s-pushback-of-migrants-shamefulun-refugee-chief. Accessed on 20 April 2021.

Amnesty International. 20 October 2020. Indonesia: Hundreds of Rohingya Need Urgent Rescue Near Aceh Waters. https://www.amnesty.org.au/indonesia-hundreds-of-rohingya-need-urgent-rescuenear-aceh-waters/. Accessed on 20 April 2021.

Rebecca Ratcliffe. 6 November 2020. Myanmar Minorities, Including Rohingya, Excluded from Voting in Election. The Guardian. https://www.theguardian.com/world/2020/nov/06/myanmar-minoritiesrohingya-excluded-voting-election-poll-aung-san-suu-kyi-rights. Accessed on 20 April 2021.

Weis, Paul. 1990. The Refugee Convention, 1951: The Travaux Préparatoires Analysed with a Commentary. UNHCR: 1-272. https://www.refworld.org/docid/53e1dd114.html. Accessed on 20 April 2021.

\section{UNHCR}

UNHCR, Global Appeal 2021 Update. https://reporting.unhcr.org/sites/default/files/ga2021/pdf/Global_ Appeal_2021_full_lowres.pdf. Accessed on 20 April 2021.

UNHCR, South East Asia: Global Appeal (Update 2015). https://www.unhcr.org/publications/fundraising/5461e60a558/unhcr-global-appeal-2015-update-south-east-asia-subregional-overview.html. Accessed on 20 April 2021.

UNHCR. 1977. Note on Non-Refoulement. (EC/SCP/2). https://www.unhcr.org/excom/scip/3ae68ccd10/ note-non-refoulement-submitted-high-commissioner.html. Accessed on 20 April 2021.

UNHCR. 1997. Note on the Principle of Non-Refoulement. https://www.refworld.org/docid/438c6d972. html. Accessed on 20 April 2021.

UNHCR. 2007. Advisory Opinion on the Extraterritorial Application of Non- Refoulement Obligations under the 1951 Convention relating to the Status of Refugees and its 1967 Protocol. http://www. refworld.org/docid/45f17a1a4.html. Accessed on 20 April 2021.

UNHCR. 2011. Handbook and Guidelines on Procedures and Criteria for Determining Refugee Status under the 1951 Convention and the 1967 Protocol Relating to the Status of Refugees. HCR/1P/4/ ENG/REV. https://www.refworld.org/pdfid/4f33c8d92.pdf. Accessed on 20 April 2021.

UNHCR. 2011. Rescue at Sea, Stowaways and Maritime Interception: Selected Reference Materials. Division of International Protection (DIP), Geneva. https://www.unhcr.org/4ee1d32b9.pdf. Accessed on 20 April 2021. 
UNHCR. 2014. A Thematic Compilation of Executive Committee Conclusions. Division of International Protection, Geneva. (7th edition). https://www.refworld.org/docid/5698c1224.html. Accessed on 20 April 2021.

UNHCR. 2014. Guidelines on Temporary Protection or Stay Arrangements. <https://www.refworld.org/ docid/52fba2404.html>. Accessed on 20 April 2021.

UNHCR. 2015. Guidelines on International Protection No. 11: Prima Facie Recognition of Refugee Status. HCR/GIP/15/11. https://www.refworld.org/docid/555c335a4.html. Accessed on 20 April 2021.

UNHCR. 2015. Thematic Compilation of General Assembly and Economic and Social Council Resolutions. Division of International Protection. https://www.unhcr.org/53b2c42c9.pdf. Accessed on 20 April 2021.

UNHCR. 2017. General Legal Considerations: Search-and-Rescue Operations Involving Refugees and Migrants at Sea. https://www.refworld.org/docid/5a2e9efd4.html. Accessed on 20 April 2021.

UNHCR. 2019. Report of the Seventieth Session of the Executive Committee of the High Commissioner's Programme https://www.unhcr.org/en-au/excom/excomrep/5db958137/70h-session-executivecommittee-report-seventieth-session-executive-committee.html. Accessed on 20 April 2021.

UNHCR. Background on the Executive Committee. 01 July 2001. https://www.unhcr.org/en-au/excom/ announce/3b4f09faa/background-executive-committee.html. Accessed on 20 April 2021.

UNHCR. South-East Asia, Mixed Maritime Movements (April - June 2015: Highlights). https://relie fweb.int/sites/reliefweb.int/files/resources/554c6a746_0.pdf. Accessed on 20 April 2021.

UNHCR. States Parties to the 1951 Convention relating to the Status of Refugees and the 1967 Protocol. https://www.unhcr.org/protect/PROTECTION/3b73b0d63.pdf. Accessed on 20 April 2021.

\section{Cases}

CPCF v Minister for Immigration and Border Protection [2015] HCA 1.

ICJ, Legal Consequences of the Construction of a Wall in the Occupied Palestinian Territory, Advisory Opinion, I. C. J. Reports 2004

Legality of the Threat or Use of Nuclear Weapons, Advisory Opinion, ICJ GL No 95, [1996] ICJ Rep 226. Lopez Burgos v Uruguay, Saldias de Lopez (on behalf of Lopez Burgos) v Uruguay, Merits, Communication No 52/1979, UN Doc CCPR/C/13/D/52/1979, IHRL 2796 (UNHRC 1981), 29th July 1981.

Minister for Immigration and Ethnic Affairs v Teoh (1995) 128 Australian Law Reports 353.

Nationality Decrees Issued in Tunis and Morocco, Advisory Opinion No. 4, 7 February 1923, P.C.I.J.

Regina v Immigration Officer at Prague Airport and Another, Ex parte European Roma Rights Centre and Others [2004] UKHL 55.

Sale v. Haitian Centers Council, 509 US 155 (1993) 183.

Western Sahara, Advisory Opinion, ICJ GL No 61, [1975] ICJ Rep 12.

\section{UN General Assembly Resolutions}

General Assembly, A/RES/36/125, 14 December 1981

General Assembly, A/RES/42/109, 7 December 1987

General Assembly, A/RES/47/105, 16 December 1992

General Assembly, A/RES/57/187, 6 February 2003

General Assembly, A/RES/61/222, 16 March 2007

General Assembly, A/RES/63/111, 12 February 2009

General Assembly, A/RES/65/37, 17 March 2011

General Assembly, A/RES/66/231, 5 April 2012

General Assembly, A/RES/67/149, 20 December 2012

General Assembly, A/RES/68/141, 18 December 2013

General Assembly, A/RES/ 69/152, 18 December 2014

General Assembly, A/RES/69/245, 24 February 2015

General Assembly, A/RES/70/235, 15 March 2016

General Assembly, A/RES/71/1, 3 October 2016 (New York Declaration for Refugees and Migrants)

General Assembly, A/RES/71/257, 20 February 2017 


\section{ExCom Conclusions of UNHCR}

ExCom Conclusion No. 1 (1975)

ExCom Conclusion No. 103 (2005)

ExCom Conclusion No. 108 (2008)

ExCom Conclusion No. 108 (2008).

ExCom Conclusion No. 14 (1979)

ExCom Conclusion No. 15 (1979)

ExCom Conclusion No. 17 (1980)

ExCom Conclusion No. 19 (1980)

ExCom Conclusion No. 2 (1976)

ExCom Conclusion No. 20 (1980)

ExCom Conclusion No. 21 (1981)

ExCom Conclusion No. 22 (1981)

ExCom Conclusion No. 23 (1981)

ExCom Conclusion No. 25 (1982)

ExCom Conclusion No. 29 (1983)

ExCom Conclusion No. 33 (1984)

ExCom Conclusion No. 38 (1985)

ExCom Conclusion No. 55 (1989)

ExCom Conclusion No. 82 (1997)

ExCom Conclusion No. 97 (2003)

ExCom Conclusion No. 97 (2003).

ExCom Conclusion No. 99 (2004)

ExCom No. 22 (1981)

Publisher's Note Springer Nature remains neutral with regard to jurisdictional claims in published maps and institutional affiliations. 